\title{
Development of an artisanal tanning method of the acoupa weakfish (Cynoscion acoupa) skin and its transfer through a workshop to a community in the city of Bragança, PA, Brazil
}

\author{
Desenvolvimento de método artesanal de curtimento da pele da \\ pescada amarela (Cynoscion acoupa), e sua difusão por meio de \\ oficina a uma comunidade no município de Bragança, PA, Brasil
}

\author{
Bruno José Corecha Fernandes Eiras ${ }^{1 *}$; Elias Fernandes Medeiros Júnior ${ }^{1}$; \\ Marileide Moraes Alves ${ }^{2}$
}

\begin{abstract}
Bragança is one of the largest fishing centers in the state of Pará, northern Brazil. In the city, there are several environmental and socio-economic problems such as lack of waste management and contamination of water sources that supply to the city and the Caeté river estuary. The social and economic problems are mainly caused by social inequality, which usually occurs in communities where the population depends mainly on fishing. Fish waste forms a part of the waste disposed in the region. Fish skin represents a significant portion of this waste and may be used for manufacturing leather by the tanning process, thereby generating income for the community and reducing environmental impacts. The acoupa weakfish (Cynoscion acoupa) has a high potential for tanning because of its large size and high yield of skin. The aim of this study was to develop a methodology for artisanal skin tanning of acoupa weakfish and the subsequent transfer of this methodology to a fishing community through a workshop. The methodology developed in the laboratory is more streamlined than traditional methods and is based on tanning methods cited in the literature and techniques applied in regional tanneries. To assess the quality of acoupa weakfish leather, resistance tests were performed, which proved its potential for manufacturing clothing and footwear. An economic analysis of the hypothetical production of leather based on the tanning methodology developed in this work revealed that the project is feasible and the effluents generated during the process are less harmful to the environment, compared to those generated by traditional tanning methods.
\end{abstract}

Key words: Fish leather, tannin, fish waste, resistance test, economic analysis

\section{Resumo}

Bragança é um dos maiores polos pesqueiros do estado do Pará, norte do Brasil. No município há problemas de ordem sócio-ambiental e econômica como: falta de gerenciamento dos resíduos, contaminação dos mananciais que abastecem a cidade e do estuário do rio Caeté. Os problemas sociais e econômicos são ocasionados principalmente pela desigualdade social, que ocorre geralmente nas comunidades onde a população sobrevive principalmente da pesca. Dentre os rejeitos descartados na região podem-se citar os resíduos do pescado. A pele do peixe corresponde a uma parte significativa

\footnotetext{
${ }^{1}$ Bacharel em Engenharia de Pesca, Universidade Federal do Pará, UFPA, Bragança, PA, Brasil. E-mail: bruno_eiras@hotmail. com; bruno.corecheiras@gmail.com.

2 Prof ${ }^{a}$ Associada, da Faculdade de Engenharia de Pesca, UFPA, Bragança, PA, Brasil. E-mail: malves@ufpa.br

* Author for correspondence
} 
desses resíduos e pode ser destinada ao curtimento, para obtenção de couro, gerando renda para comunidade e reduzindo impactos ambientais. Dentre os peixes com potencial para o curtimento, pode-se citar a pescada amarela (Cynoscion acoupa) pelo grande porte a alto rendimento em pele. $\mathrm{O}$ objetivo deste estudo foi desenvolver uma metodologia de curtimento artesanal da pele da pescada amarela e sua posterior transferência a uma comunidade pesqueira, sob forma de oficina. A metodologia desenvolvida em laboratório é mais simplificada que as tradicionais e foi baseada em métodos de curtimento citados na literatura e técnicas aplicadas em curtumes regionais. Para avaliar a qualidade do couro da pescada amarela, foram feitos testes de resistência, que comprovaram seu potencial para confecção em vestuários e calçados. Em uma análise econômica da produção hipotética de couro com a metodologia de curtimento desenvolvida neste trabalho constatou-se que o empreendimento é viável, além dos efluentes gerados durante o processo ser menos agressivos ao ambiente, comparado com os resíduos gerados pela metodologia tradicional de curtimento.

Palavras-chave: Couro de peixe, tanino, resíduo de pescado, teste de resistência, análise econômica

\section{Introduction}

The north of Brazil stands out from other regions of the country for its fish production. In 2010, the north was the leading national producer by continental extractive fishing, producing 138,726 tons. Fish production is a part of the tradition of the Brazilian state of Pará and is of great importance in the north. In 2010, it was the second largest national producer of fish by extractive marine fishing and the leading producer of fish in the north, producing 87,585 tons. With regard to continental extractive fishing, the states of Pará and Amazonas produced 50,949 and 70,896 tons respectively, accounting for half the national production of fish (MPA, 2012).

The municipality of Bragança is situated in the middle of the northeast of Pará and in the microregion of Bragantina located between latitude $01^{\circ} 03^{\prime} 15^{\prime \prime} \mathrm{S}$ and longitude $46^{\circ} 46^{\prime} 10^{\prime \prime} \mathrm{W}$ (PACHECO et al., 2011). This is one of the largest fishing centers in the state of Pará, with the largest fishing disembarkation of the region, together with the municipalities of Belém and Vigia. The acoupa weakfish (Cynoscion acoupa) is one of the species with high economic importance in the region, with excellent meat quality and is highly preferred by the population of Bragança (FURTADO JÚNIOR et al., 2006; MOURÃO et al., 2009).

In Bragança-PA, there are several problems associated with solid waste management: highly disorganized occupation; lack of basic sanitation; a garbage disposal site that does not meet the technical specification for land fill, located centrally and less than $3 \mathrm{~km}$ from the Chumucuí River (main source for the city); exposure to solid waste and open burning of garbage; the lack of effluent treatment; and no adequate draining of effluents into the Caeté River. Because of these reasons, the water quality is gradually deteriorating and damaging the ecosystem. This scenario also causes socioeconomic problems, due to devaluation of the area, which is polluted by fishing, tourism, leisure, and also raises public health concerns due to the proliferation of diseases (GORAYEB et al., 2009).

According to Article 18 of Law No. 12.305/ August 2, 2010, the municipality should prepare a plan for the management of solid waste in order to assess the financial resources of the union and to implement necessary measures for solid waste management. Article 33 of the same law determines how reverse logistics is to be carried out, i.e., a set of actions to be taken by the producer of the waste, for the possible reuse of solid waste, or another environmental friendly final destination (BRASIL, 2012).

Waste generated from fish processing account for approximately $65 \%$ of the total weight, as the yield from fillets is approximately $35 \%$. Skin accounts for $4.5 \%$ to $14 \%$ of the total weight, and is one of the components of waste that is not usually used because of the lack of knowledge about its alternative uses 
(SOUZA, 2004; BOSCOVO; FEIDEN, 2007).

Fish skin is one of the most commonly discarded wastes in the Extractive Reserve (RESEX) area in the northeast of Pará, damaging the environment and the health of the population; it can be transformed into leather through the tanning process, representing an alternative source of income, and may contribute to the local socioeconomic development (MARTINS, 2010).

Communities making a living from artisanal fishing are in a state of poverty, with other associated problems, including a low level of social organization, competition with industrial embarkations, which reduces the availability of many fish species, fish sold cheaply to intermediaries, who represent the first purchaser and reseller of fish in the delivery system, amongst other obstacles (SANTOS, 2005).

This study aims to develop artisanal tanning techniques of fish skin and transfer the technology through workshops to the members of the fishing community for an alternative income source and to reduce the volume of organic matter discarded into the environment.

\section{Materials and Methods}

The methodology involved elaboration of the artisanal tanning method, leather resistance test, transfer of the developed methodology through workshops to the fishing community of BragançaPA, as well as a hypothetical economic analysis of leather production.

Hide of the acoupa weakfish with average dimensions of $60 \mathrm{~cm}$ length and $15 \mathrm{~cm}$ width and a mean weight of $180 \mathrm{~g}$, were obtained from a fish processing plant in the region and refrigerated at $-18^{\circ} \mathrm{C}$. For the experiment, the hides were defrosted at room temperature $\left(25^{\circ} \mathrm{C}\right)$.

Mimosa plant extract (commercial name "Supertan" from the company TANAC S.A.) was used as a tanning agent and andiroba (Carapa guianensis) oil, used as grease, was applied directly to the hide.

\section{Elaboration of the artisanal tanning method}

First, experiments were conducted at the Fish Technology Laboratory, the Federal University of Pará (UFPA) campus, Bragança-PA, to develop a simplified artisanal method (Figure 1) based on modified methodologies of SEBRAE (1996), Souza (2004), Souza (2006), and empirical tanning techniques applied in local tanneries.

Figure 1. A flow diagram of the stages of artisanal tanning in the laboratory.

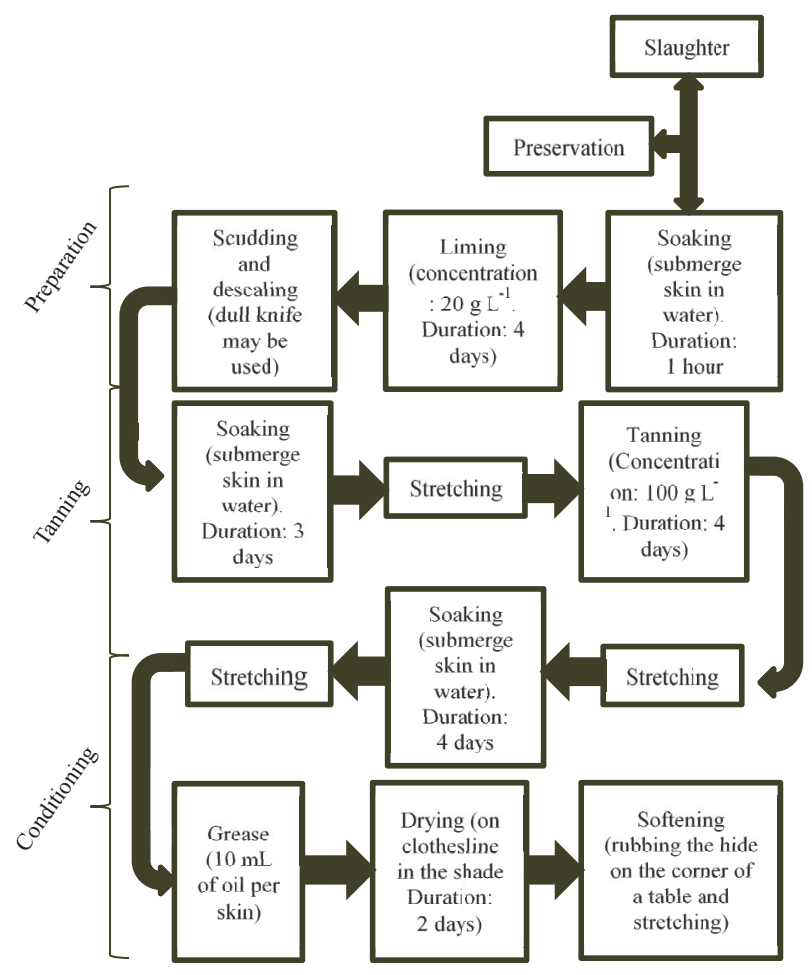

According to the methodology developed in this study, the hide used for tanning can be preserved by salting or freezing, if salt is used, it must be removed before tanning. The tanning process is divided into three stages: 1$)$ preparation: the hide is cleaned and the fibers are prepared for the tanning agent, 2) tanning: the tanning agent is 
applied to the hide, transforming it into leather, and 3 ) conditioning: the leather is treated for softness and malleability.

Preparation involved soaking, liming, scudding, and deliming. Soaking is the initial cleaning process of the hide, and involved submerging the hide in water for $1 \mathrm{~h}$ or until defrosting or removal of salt. Liming was performed using a solution of hydrated lime (concentration $20 \mathrm{~g} \mathrm{~L}^{-1}$ ). For each hide, $1 \mathrm{~L}$ of limewater was used and the hides remained in the solution for 4 days. Then the hides were washed under running water and the scales and flesh attached to the hides were removed using a dull knife (artisanal tool with a wooden base and unsharpened blade).

Tanning involved soaking, stretching, and tanning. Soaking aims to remove the lime by adding enough water to immerse the hide and changing the water daily for 4 days. After soaking, the hides are stretched. A solution of mimosa tannin (concentration $100 \mathrm{~g} \mathrm{~L}^{-1}$ ) was used for tanning, with $1 \mathrm{~L}$ of the tannin solution being used per hide. The hides remained in the tannin solution for 4 days.

Conditioning involved soaking, greasing, drying, and softening. The hide was stretched before and after soaking. Water was changed daily for 4 days, greasing was done by directly applying the andiroba oil onto the hide, using approximately $10 \mathrm{~mL}$ of oil per hide. After this process, the hides were placed on a clothes line for 2 days under shade to remove moisture. After drying, they were rubbed on a table corner and stretched to ensure final softness.

The liming, soaking, and tanning stages were carried out in $20 \mathrm{~L}$ plastic buckets. The scudding, deliming, stretching and greasing stages were carried out on polyethylene boards.

To assess the influence of the liming stage on the quality of the final product, pilot tests that omitted this step were performed, thereby simplifying the methodology developed in the laboratory. The randomized experimental design included two treatments: tanned hides with and without the liming stage with three replicates.

\section{Resistance test}

The resistance test was conducted in the Mechanical Engineering Laboratory of UFPA. After measuring the thickness of the samples (ABNT NBR 11062, 2005), the proof-bodies were removed (ABNT - NBR 11035, 1990). Then the traction and stretching tests were applied (ABNT -NBR 11041, 1997). The results were analyzed using analysis of variance (ANOVA).

\section{Methodology transfer}

After developing the artisanal tanning methodology and the resistance test for the obtained hide, the technology was transferred through a workshop to the community of Castelo, municipality of Bragança-Pa $\left(00^{\circ} 56^{\prime} 43^{\prime \prime} \mathrm{S} 46^{\circ} 45^{\prime} 58^{\prime \prime} \mathrm{W}\right)$. The workshop was conducted for a group of 24 fishermen wives, between 25 and 53 years age, who work in fish scale crafting.

First, audio-visual aids were used to emphasize the environmental significance of utilizing fish skin and the financial benefits of fish leather obtained from the tanning process. Then, the tanning procedure developed in the laboratory was demonstrated.

\section{Economic analysis}

The investments and profits of producing hide from the acoupa weakfish were estimated based on prices of products and tools in shops, supermarkets, and on the Internet. The economic analysis calculations were based on SEBRAE procedures (1996) (Table 1). 
Table 1. Economic analysis calculations.

\begin{tabular}{cc}
\hline Indices & Equations \\
\hline Marketing index (MI) & Fixed value of $32.65 \%$ \\
Profit margin (PM) & Fixed value of $30 \%$ \\
Tagging rate (TR) & $\mathrm{TR}=[100-(\mathrm{MI}+\mathrm{PM})] / 100$ \\
Sale unit price (SUP) & $\mathrm{SUP}=$ Unit production cost $/ \mathrm{TR}$ \\
Total sale price (TSP) & $\mathrm{TSP}=\mathrm{SUP} \times$ Monthly production \\
Operating profit (OP) & $\mathrm{OP}=\mathrm{TSP}-($ Fixed cost + Variable cost $)$ \\
Social contribution index (SCI) & Fixed value of $9.09 \%$ \\
Income tax (IT) & Fixed value of $25 \%$ \\
Net income (NI) & NI $=$ OP $-(\mathrm{SCI}+\mathrm{IT})$ \\
Contribution margin (CM) & $\mathrm{CM}=\mathrm{TSP}-$ Variable cost \\
Break-even point (BEP) & $\mathrm{BEP}=($ Fixed cost $/ \mathrm{CM}) \mathrm{x} 100 \%$ \\
Profitability index (PI) & PI $=(\mathrm{NI} / \mathrm{TSP}) \times 100 \%$ \\
Rate of return $(\mathrm{RR})$ & $\mathrm{RR}=\mathrm{Initial}$ investment $/ \mathrm{NI} \times 12$ \\
\hline
\end{tabular}

The marketing index includes all sales taxes, the profit margin is the percentage gain above the sale of a product, the tagging rate is used to calculate the sale price, the operating profit is the total sale price after subtracting the fixed and variable costs, net income is income minus product taxes, the contribution margin is considered when calculating the break-even point, which is the minimum revenue required for the company not to experience losses, and the rate of return is the period in which income exceeds the company expenses.

\section{Results and Discussion}

The hides tanned without the liming stage became stiffer, whereas those tanned with the liming stage incorporated led to soft hide. Soaking helped decrease the $\mathrm{pH}$ of the hide. The $\mathrm{pH}$ of water in Bragança-PA is acidic, varying between 5 and 6 (GORAYEB et al., 2010), which may have contributed to the acidification of the soaking solution, since the initial $\mathrm{pH}$ of the soaking solution varied between 12-9 during the initial days. After 3 days, the solution was attenuated, and $\mathrm{pH}$ dropped to $8-6$, which was desirable for the tannin to diffuse through the dermis. The $\mathrm{pH}$ of the tannin solution was approximately 5.5, which may also have helped to decrease the $\mathrm{pH}$ of the hide during tanning diffusion.

According to Souza (2004), during this stage, the $\mathrm{pH}$ values should vary between $4.0-5.6$, because in this range, the affinity of the tanning agent for protein is minimal, thereby allowing the tanning agent to penetrate quickly due to the low reactivity with fibers. This may suggest that the soaking stage substitutes the deliming and pickling stages, which are the stages in the traditional tanning process.

Stretching may also have contributed to the efficient diffusion of the tanning agent, since removing flesh remnants reduced the thickness of the hide, with more stretched fibers, as well as removing the most outer interfiber substances, reducing the physical resistance to the penetration of the tanning agent. Further studies are required to prove this hypothesis whether stretching can be an alternative to purging.

The concentration of tannin and tanning time 
were sufficient to tan the hide of acoupa weakfish, confirmed by the boiling test (MELO, 2007), which assured the thermal stability of the hide.

Greasing with andiroba oil contributed to the final softness of the hide. According to Heidemann (1993), a good grease for hide must contain 14 to 18 carbon chain fatty acids, since oils with fewer carbons give rise to rough and less flexible hide. Andiroba oil is rich in 18 carbon unsaturated fatty acids (LAGO; SIQUEIRA, 1980).

Unlike the methodologies found in the literature, the method developed in this study uses only water, lime, vegetable tannin, and vegetable oil, resulting in effluents containing these substances, flesh remains, hide, and scales, which are less polluting when compared with effluents containing chemical reagents used in traditional tanning. The total time of the tanning process in this study, 18 days, is longer than that in traditional methods, since additional chemicals such as sulphates, tensoactives, acids, bases, or chromium (tanning agent) were not used. The longer tanning process is compensated by fewer chemical components in the effluents.
The tanning technique described by Souza (2006) is most similar to that used in this study, as it uses alternative methods to the traditional tanning process. The methods described by SEBRAE (1996) and Souza (2004) are most similar to the traditional method, with a wider range of chemical agents and more complex tanning processes, which make it more difficult for a workshop community to learn and are more costly in terms of creating an artisanal tannery.

With regard to the resistance test, the hides which involved the liming stage (Table 2) showed better resistance to traction at $44.56 \mathrm{~N} \mathrm{~mm}^{-2}$, stretching at $62.53 \%$, and load with a resulting force of 513.91 $\mathrm{N}$, whereas hides which did not involve the liming phase showed resistance to traction of $15.52 \mathrm{~N} \mathrm{~mm}^{-}$ 2 , stretching of $13.08 \%$, and force of $212.36 \mathrm{~N}$. The difference between treatments could have occurred due to less amount of tanning agent being absorbed by the hide which did not involve the liming stage, which affected the quantity of the interfiber material and led to smaller aperture of the fibers, making the hide more rigid, a feature also reported by Souza (2004).

Table 2. Tension and stretching test of acoupa weakfish (Cynoscion acoupa) hide using two different tanning processes (with and without liming), tanned with mimosa tannin (supertan), and greased with andiroba oil (Carapa guianensis).

\begin{tabular}{cccc}
\hline Treatment & Maximum force $(\mathrm{N})$ & $\begin{array}{c}\text { Maximum tensile strength } \\
\left(\mathrm{N} \mathrm{mm}^{-2}\right)\end{array}$ & Stretching (\%) \\
\hline Tanning with liming stage & $513.91 \pm 79.15$ & $44.56 \pm 2.39$ & $62.53 \pm 29.54$ \\
Tanning without liming stage & $212.36 \pm 77.36$ & $15.52 \pm 7.15$ & $13.08 \pm 7.48$ \\
\hline F test & 40.97 & 26.16 & 66.79 \\
\hline
\end{tabular}

Guimarães (2010) and Barreto (2012) performed experiments analyzing the influence of some types of oils in the resistance of the Nile tilapia (Oreochromis niloticus) hide and found that the different oils influenced the resistance of the hide. Therefore, further studies comparing hides greased with andiroba oil and other types of oils are required to assess whether there is any effect of these oils on the physico-mechanical properties.

Souza et al. (2006) performed histological analyses and resistance test on the hide of the silverplated carp (Hypophtalmichthys molitrix) tanned with plant tannin and chromium and found that the hide of the silver-plated carp is composed of a thick dermis and with collagen fibers parallel and transverse to the hide surface, which according to 
the authors, confers resistance to the hide. The hide tanned with chromium had a greater resistance to traction at $16.96 \mathrm{~N} \mathrm{~mm}^{-2}$, tensile strength of 104.74 $\mathrm{N}$ and stretching of $51.49 \%$ compared with those tanned using tannins: $9.12 \mathrm{~N} \mathrm{~mm}^{-2}, 58.81 \mathrm{~N}$, and $17.48 \%$, respectively.

Gomes (2008) studied the histological characteristics of hide of the acoupa weakfish ( $C$. acoupa) and smooth weakfish (C. leiarchus), and confirmed that both have the same arrangement of birefringent collagen fibers, forming thick and twisted fibers, arranged both longitudinally and transversally. This arrangement of collagen fibers in the acoupa weakfish is similar to the silver-plated carp mentioned by Souza et al. (2006). The resistance test, however, revealed that the acoupa weakfish hide was more resistant than that of the silver-plated carp tanned with plant tannin or chromium.

Vieira et al. (2008) tested the resistance of Nile tilapia hide tanned with different concentrations of plant tannins, synthetic tannin, and a mixture of tanning agents and found that the hides tanned with synthetic tannin, regardless of the concentration, showed the lowest resistance, while the hides tanned with plant tannins in concentrations of $10 \%$ and $12 \%$ and a mixture of tanning agents conferred the highest resistance. This indicates that the concentration of tannin used to tan the hide of the acoupa weakfish was ideal for good resistance and elasticity of the hide.

Hide of the acoupa weakfish that did not undergo liming is not suitable for use in garments or footwear since its resistance to traction is 15.52 $\mathrm{N} \mathrm{mm}{ }^{-2}$ and stretching of $13.08 \%$, less than the minimum required, whereas the hide subjected to liming can be used for garments and footwear since it has a resistance to traction of $44.56 \mathrm{~N} \mathrm{~mm}^{-2}$ and stretching of $62.53 \%$ above the minimum required. According to BASF (2004) for wet blue bovine hide to be used in the clothing and footwear industry, it must have a minimum resistance to traction of $20 \mathrm{~N}$ $\mathrm{mm}^{-2}$ and a stretching resistance greater than $40 \%$.

The economic analysis was performed using an estimated production of $20 \mathrm{~m}^{2}$ of acoupa weakfish hide, corresponding to 240 pieces of hide weighing $43 \mathrm{Kg}$ (Tables 3, 4 and 5). To tan an acoupa weakfish hide, with an average dimension of $60 \mathrm{~cm}$ in length $\times 15 \mathrm{~cm}$ in width and weight of $180 \mathrm{~g}, 20 \mathrm{~g}$ of lime, $100 \mathrm{~g}$ of tannin, $10 \mathrm{~mL}$ of andiroba oil, and1 $\mathrm{L}$ of water are required. To produce $1 \mathrm{~m}^{2}$ of acoupa weakfish hide, approximately 12 pieces of hide, of the dimensions cited, were required.

Table 3. Fixed investment for the production of $20 \mathrm{~m}^{2}$ of acoupa weakfish (Cynoscion acoupa) hide. ${ }^{1}$

\begin{tabular}{ccccc}
\hline Discrimination & Unit & Unit value $(\mathrm{R} \$)$ & Quantity & Total value $(\mathrm{R} \$)$ \\
\hline Wooden bench & Dimensions $1.5 \times 0.5 \mathrm{~m}$ & $1,300.00$ & 1 & $1,300.00$ \\
Fiber Water tank & $250 \mathrm{~L}$ & 85.00 & 2 & 170.00 \\
Electronic scale & - & 559.00 & 1 & 559.00 \\
Stainless steel machete & - & 5.00 & 10 & 50.00 \\
Stainless steel soup spoon & - & 2.00 & 10 & 20.00 \\
Polyethylene rope & $15 \mathrm{~m}$ & 8.00 & 1 & 8.00 \\
Nailer & 100 units & 14.00 & 2 & 28.00 \\
Telephone line & - & 29.00 & 1 & 29.00 \\
Submerged pump & - & $1,500.00$ & 1 & $1,500.00$ \\
Freezer & - & 950.00 & 1 & 950.00 \\
\hline Total & - & - & - & $4,614.00$
\end{tabular}

${ }^{1}$ Prices researched in shops, supermarkets, and on the Internet.

${ }^{2}$ May be substituted with a dull knife. 
Table 4. Fixed monthly costs for the production of $20 \mathrm{~m}^{2}$ of acoupa weakfish (Cynoscion acoupa) hide. ${ }^{1}$

\begin{tabular}{cc}
\hline Breakdown & Value $(\mathrm{R} \$)$ \\
\hline Telephone & 29.00 \\
Electrical energy & 50.00 \\
Freight & 60.00 \\
\hline Total & 139.00 \\
\hline
\end{tabular}

${ }^{1}$ Prices researched in shops, supermarkets, and on the Internet.

Table 5. Variable cost for the production of $20 \mathrm{~m}^{2}$ of acoupa weakfish (Cynoscion acoupa) hide. ${ }^{1}$

\begin{tabular}{ccccc}
\hline Breakdown & Unit & Unit value $(\mathrm{R} \$)$ & Quantity & Total value $(\mathrm{R} \$)$ \\
\hline Virgin lime & $25 \mathrm{~kg}$ & 16.00 & 1 & 16.00 \\
Mimosa tannin & $25 \mathrm{~kg}$ & 140.00 & 1 & 140.00 \\
Andiroba oil & $100 \mathrm{PM}$ & 50.00 & 3 & 150.00 \\
Acoupa weakfish hide $^{2}$ & Dimensions $60 \times 15 \mathrm{~cm}$ & - & 240 & - \\
\hline Total & & - & - & 306.00 \\
\hline
\end{tabular}

${ }^{1}$ Prices researched in shops, supermarkets, and on the Internet.

${ }^{2}$ The hides may be obtained through donation after fileting.

For the group of women in the community of Castelo to begin to learn artisanal tanning, it is necessary to obtain a capital of $\mathrm{R} \$ 5,504.00$ corresponding to a working capital of $\mathrm{R} \$ 445.00$ and costs of R\$ 5,059.00 (fixed investment, fixed monthly costs, and variable costs) (Table 3, 4, and 5).

Table 6. Products using acoupa weakfish (Cynoscion acoupa) hide (monthly production of 240 hides).

\begin{tabular}{ccccc}
\hline Product & $\begin{array}{c}\text { Quantity of hides } \\
\text { (unit) }\end{array}$ & $\begin{array}{c}\text { Unit cost of } \\
\text { material }(\mathrm{R} \$)\end{array}$ & $\begin{array}{c}\text { Unit price of hide } \\
(\mathrm{R} \$)\end{array}$ & $\begin{array}{c}\text { Sale unit price } \\
(\mathrm{R} \$)^{1}\end{array}$ \\
\hline Small female purse & 1 & 90.00 & 4.96 & 94.96 \\
Female belt & 1 & 20.00 & 4.96 & 24.96 \\
Female sandals & 1 & 130.00 & 4.96 & 134.96 \\
Male wallet & 1 & 25.00 & 4.96 & 29.96 \\
\hline
\end{tabular}

${ }^{1}$ Unit sale price of the acoupa weakfish hide R\$ 4.96 with a profit margin of $30 \%$.

The economic analysis of the tanning process for the production of $20 \mathrm{~m}^{2}$ of hide and handicrafts is shown in (Table 7). This process is viable, since
To predict the profit of producing fish hide artefacts (Table 6), an economic analysis was performed on some acoupa weakfish artefacts, based on the initial investment, fixed, and variable costs, and taking into account a monthly production of 240 pieces of acoupa weakfish hide of the specified sizes. the profitability index is $59.79 \%$, with the minimum required by the company is $15.70 \%$ and the rate of return is 7 and a half months ( 0.64 years). 
Table 7. Economic analysis of the production of acoupa weakfish (Cynoscion acoupa) hide per square meter and handicrafts.

\begin{tabular}{ccc}
\hline Financial calculations & $\begin{array}{c}\text { Calculation for the production of } \\
20 \mathrm{~m}^{2} \text { of hide }\end{array}$ & $\begin{array}{c}\text { Calculation for the production of } \\
\text { handicrafts }(240 \text { hides })\end{array}$ \\
\hline Tagging rate (TR) & 0.3735 & 0.3735 \\
Product unit cost (PUC) (R\$) & 22.25 & 1.85 \\
Sale unit price (SUP) (R\$) & 59.57 & 4.96 \\
Total sale price (TSP) (R\$) & 1.191 .43 & 1.191 .43 \\
Operating profit (OP) (R\$) & 746.43 & 746.43 \\
Net income (NI) (R\$) & 712.34 & 712.34 \\
Contribution margin (CM) (R\$) & 885.43 & 885.43 \\
Break-even point (BEP) (\%) & 15.70 & 15.70 \\
Profitability index (PI) (\%) & 59.79 & 59.79 \\
Rate of return (RR) (years) & 0.64 & 0.64 \\
\hline
\end{tabular}

Price per meter square of acoupa weakfish hide calculated in this study is below the sale price per meter square of tilapia hide (Oreochromis niloticus) in Maringá-PR, varying from R\$ 150,00 to 200,00 per meter square (Martins, 2010). With regard to the price of handicrafts, Martins (2010) cited some values of products based on fish hide of a fictitious company "Ictiocouro" with differences in some products at higher prices than those in this study (purse R\$160.00, wallet R\$100.00, sandals $\mathrm{R} \$ 40.00)$. The price of the product may vary significantly, depending on the location, market, demand, logistics, price of equipment, reagents, tools, and freight, among other factors.

The transfer of the artisanal tanning methodology in the community was satisfactory; the simplicity of the tanning method used facilitated its learning and the results obtained for the acoupa weakfish, generated interest in the production of hide to increase family income.

Malufand Hilbig (2010) conducted a similarstudy and demonstrated an artisanal tanning technique using a vegetable tannin called "ecological tannin" for the community of Cantuquiriguaçu in the state of Paraná; this community is similar to communities in Bragança-PA in terms of the by-product wastes and environmental impact of these wastes.
In another similar study by Cotrim et al. (2007), training courses in fish hide handicraft were provided to a group of fishermen wives in the municipality of Tramandaí-RS, which provided greater expansion of citizenship and greater social inclusion.

\section{Conclusion}

The development and transfer of an alternative methodology for the artisanal tanning of the acoupa weakfish hide was successful, since the existing methods in the literature use various chemical reagents and various complex steps that may complicate the understanding of this process in a traditional community. The resistance test showed that the hide that was treated with limewater, tanned with mimosa vegetable tannin, and greased with andiroba oil showed sufficient resistance to traction and to stretching, and could be used for manufacturing clothing and footwear. The economic analysis showed that the tanning of fish hide using the methodology developed in this study was viable. The artisanal tanning method developed in this study (which included the liming stage) is a promising method to enhance the quality of acoupa weakfish hide, with less impact on the environment, and represents better involvement of artisanal women in the community, as well as would 
help in bridging the gap between the university and the community.

\section{Acknowledgments}

To the Federal University of Pará (UFPA), Corporation for Technical Assistance and Rural Extension of the state of Pará (EMATER-PA) for the logistics and to the community of Castelo, municipality of Bragança-PA, for their receptivity.

\section{References}

ASSOCIAÇÃO BRASILEIRA DE NORMAS TÉCNICAS - ABNT. NBR 11035: corte de corposde-prova em couro. Associação Brasileira de Normas Técnicas, Rio de Janeiro, 1990. p. 1.

ABNT. NBR 11041: couro - determinação da resistência à tração e alongamento. Associação Brasileira de Normas Técnicas, Rio de Janeiro, 1997. p. 1-5.

ABNT. NBR 11062: couro - determinação da espessura. Associação Brasileira de Normas Técnicas, Rio de Janeiro, 2005. p. 1.

BARRETO, L. C. S. Efeitos de óleos alternativos sobre a resistência do couro da tilápia Oreochromis niloticus (Linnaeus, 1758). 2012. Monografia (Graduação em Engenharia de Pesca) - Faculdade de Engenharia de Pesca, Universidade do Estado da Bahia, Paulo Afonso.

BASF - Chemical company. Vade-Mécum do curtidor. 4. ed. Ludwigshafen: Badische Anilin \& Soda Fabrik, 2004. $441 \mathrm{p}$.

BOSCOVO, W. R.; FEIDEN, A. Industrialização de tilápias. Toledo: GFM Gráfica \& Editora, 2007. 172 p.

BRASIL. Politica nacional de resíduos sólidos. 2. ed. Brasília: Câmara dos Deputados, Edições Câmara, 2012. 74 p. (Série Legislação, n. 81).

COTRIM, D.; KOLLET, M.; DIETZ, D. Agroecologia e pesca artesanal: ampliação da cidadania através do artesanato em escama de peixe. Revista Brasileira de Agroecologia, Porto Alegre, RS, v. 2, n. 2, p. 261-264, 2007.

FURTADO JÚNIOR, I.; TAVARES, M. C. S.; BRITO, C. S. F. Estatísticas das produções de pescado estuarino e marítimo do estado do Pará e políticas pesqueiras. Boletim do Museu Paraense Emílio Goeldi Ciências Humanas, Belém, v. 1, n. 2, p. 95-111, 2006.
GOMES, S. C. S. Histologia da pele das pescadas: Amarela (Cynoscion acoupa) e branca (Cynoscion leiarchus). 2008. Monografia (Graduação em Ciências Biológicas) - Faculdade de Ciências Biológicas, Universidade do Estado do Maranhão, São Luís.

GORAYEB, A.; LOMBARDO, M. A.; PEREIRA, L. C. C. Condições ambientais em áreas urbanas da bacia hidrográfica do rio caeté - amazônia oriental - Brasil. Revista da Gestão Costeira Integrada, Portugal, v. 9, n. 2, p. 59-70, 2009.

Qualidade da água e abastecimento na Amazônia: o exemplo da bacia hidrográfica do rio Caeté. Mercator, Fortaleza, v. 9, n. 18, p. 135-157, 2010.

GUIMARÃES, C. L. Efeito dos óleos vegetal (Ref. 255-460) e de coco utilizados na etapa de engraxe sobre a resistência do couro da tilápia Oreochromis niloticus, Linnaeus, 1758. 2010. Monografia (Graduação em Engenharia de Pesca) - Faculdade de Engenharia de Pesca. Universidade do Estado da Bahia, Paulo Afonso.

HEIDEMANN, E. Fundamentals of leather manufacture. Darmstadt: Eduard Roether KG, 1993. 647 p.

LAGO, R. C. A.; SIQUEIRA, F. A. R. Composição química dos óleos de pracaxi e andiroba. Boletim técnico do CTAA, Rio de Janeiro, v. 14, n. 4, p. 1-58, 1980.

MALUF, M. L. F.; HILBIG, C. C. Curtimento ecológico de peles de animais para agregação de valor através da confecção de artesanato. Revista Varia Scientia, Cascavel, v. 9, n. 15, p. 75-79, 2010.

MARTINS, A. A. F. A. Caminho das águas: proposta para o aproveitamento de um subproduto ictiológico na Reserva Extrativista Mãe Grande de Curuçá, Pará, Brasil. 2010. Dissertação (Mestrado em Gestão de Recursos Naturais e Desenvolvimento Local na Amazônia) - Universidade Federal do Pará, Belém.

MELO, K. S. G. Extração e uso de corantes vegetais da Amazônia no tingimento do couro do Matrinxâ (Brycon amazonicu Spix \& Agassiz, 1819). 2007. Dissertação (Mestrado em Ciências Agrárias) - Instituto Nacional de Pesquisas da Amazônia, Universidade Federal do Amazonas, Manaus.

MOURÃO, K. R. M.; FRÉDOU, F. L.; ESPÍRITOSANTO, R. V.; ALMEIDA, M. C.; SILVA, B. B.; FRÉDOU, T.; ISAAC, V. Sistema de produção pesqueira pescada amarela - Cynoscion acoupa Lacèpede (1802): um estudo de caso no litoral nordeste do Pará - Brasil. Boletim do Instituto de Pesca, São Paulo, v. 35, n. 3, p. 497-511, 2009. 
MINISTÉRIO DA PESCA E AQUICULTURA - MPA. Boletim estatístico da pesca e aquicultura referentes ao ano de 2010. Ministério da Pesca e Aquicultura, Brasil, 2012. 129 p.

PACHECO, J. J.; PALHETA, M. V. O.; COSTA JÚNIOR, R. N. F.; COSTA, S. V.; TOSTES, W. S. Estatística municipal do município de Bragança. Governo do Estado do Pará: Belém, 2011. 48 p.

SANTOS, M. A. S. A cadeia produtiva da pesca artesanal no estado do Pará: estudo de caso no nordeste paraense. Amazônia: Ciência \& Desenvolvimento, Belém, v. 1, n. 1, p. 61-81, 2005.

SERVIÇO BRASILEIRO DE APOIO ÀS MICRO E PEQUENAS EMPRESAS - SEBRAE. Como montar curtume de pele e couro de peixe. Serviço Brasileiro de Apoio às Micro e Pequenas Empresas. 2. ed. Brasília: Série Oportunidade e Negócios, 1996. 33 p.
SOUZA, S. M. L. Cartilha de curtimento vegetal de pele de peixes. Canindé: Instituto de Desenvolvimento Cientifico e Tecnológico de Xingó, 2006. 22 p.

SOUZA, M. L. R. Tecnologia para processamento das peles de peixe. Maringá: Eduem, Coleção Fundamentum, 2004. 59 p.

SOUZA, M. L. R.; GODOY, L. C.; KOZUKI, H. T.; CASACA, J. M.; DOURADO, D. M.; JACINTO, M. A. C. Histologia da pele da carpa prateada (Hypophtalmichthys molitrix) e testes de resistência do couro. Revista Brasileira de Zootecnia, Brasília, v. 35, n. 4, p. 1265-1272, 2006.

VIEIRA, A. M.; KACHBA, Y. R.; FRANCO, M. L. R. S.; OLIVEIRA, K. F.; GODOY, L. C.; GASPARINO, E. Curtimento de pele de peixe com tanino vegetal e sintético. Acta Scientiarum. Animal Sciences, Maringá, v. 30, n. 3, p. 359-363, 2008. 
